\title{
The Curriculum Integration and Cooperative Learning through the Art and Entrepreneurship Project in the Integrated Technical Course in Administration at a Federal Institute - Brazil
}

\author{
Anna Carolina Salgado Jardim ${ }^{1}$, Frank Viana Carvalho ${ }^{2}$ \\ Federal Institute of Education, Science and Technology of São Paulo, Brazil
}

\begin{abstract}
This article discusses a Teaching Project developed within a Federal Institute of Education, Science and Technology, in which the Cooperative Learning methodology was used to develop an experience of curricular integration. The proposal of curricular integration was made through the curricular components of 'Projects and Entrepreneurship' and 'Integrating Project' throughout the academic year of 2015. The subjects of the research were the 24 students of the 3rd year class of the Technical Course in Integrated Administration To the High School, whose age range varied between 16 and 19 years. The results demonstrate the effective evolution of the groups with respect to interpersonal relationships, conflict resolution capacity, improved verbal, written and corporal expression and communication, a significant increase in empathy, cooperation between peers, mutual respect and of the feeling of collectivity.
\end{abstract}

Keywords: Curricular Integration; Cooperative Learning; Interdisciplinarity, Federal Institute - Brazil.

\section{INTRODUCTION}

The Technical High School courses in Brazil have undergone several transformations over the last decades and three main models of this type of training are presented at the Federal Institutes of Education, Science and Technology in Brazil (acronym IF): concomitant, subsequent and integrated. In the concomitant modality, the student must be attending the second or third year of high school in another teaching institution and, in parallel, he takes the technical course (the professional and technical training subjects) in the IF. In the subsequent modality, it is necessary that the student has already finished high school, to then study the subjects of technical training. In the integrated curriculum, the student simultaneously completes the high school and the technical course of the chosen area in the same institution - that is, the course involves both the disciplines of the National Curricular Common Core (compulsory in Brazil High School level) and the disciplines of formation Professional and Technical.

The operationalization of the integrated curriculum has been a great challenge for teachers of IFs. Since its inception (Law 11,892, dated December 29, 2008), one of the objectives of the Federal Institutes is to provide $50 \%$ of the vacancies for teaching at a technical level, preferably by means of technical courses Integrated to secondary education.

Among the difficulties is the very understanding of the teachers who work with the model. This difficulty in understanding the concept of integrated curriculum has been the focus of research and one of the answers lies in the faculty's own formation, based on the fragmentation of knowledge, which has prevented or made it difficult for curriculum integration to be no more than a denomination that Is given to vocational secondary education in the context of the Federal Institutes. And, undoubtedly, the limited pedagogical achievement in this knowledge leads to fragmented and isolated student positions.

However, the operationalization that helps to overcome these limitations is due to the action of the teachers, as well as to the mechanisms and strategies of teaching and learning with the students. And the more integration and dialogue between curriculum content and didactic integrative and cooperative practices, the easier it will be to understand and effectively operationalize the integrated curriculum.

Considering the contents provided in the Project of the Technical Course in Integrated Administration to High School for the curricular components of Projects and Entrepreneurship - where it is foreseen 
the development of concepts and abilities related to the creativity and the capacity of elaboration of projects -, as well as of Integrative Project - where the development of Internships and / or Final Research Work is envisaged, it is understood as an opportunity to integrate the curriculum with the development of competencies, skills and sensibilities that favor an entrepreneurial approach aimed at the sense of collectivity, the embryo of one of the activities more important in today's society and a means by which the sense and professional creativity are propagated that can, in fact, privilege the common good.

In this sense, actions were planned that included the intersection of the multiple languages of art associated with the studies on the Universal Declaration of Human Rights. This was the starting point so that the contents foreseen in the course were in fact absorbed by the individual student, and that they became anchor of meanings whose social and professional sense were then removed and transformed into singular, ethical, innovative and cooperative ways of acting in the world of work.

The Federal Institute of Education, Science and Technology where this Project of Education was developed is an institution that seeks to train technicians, technologists and graduates preparing them for quality professional practices. These future professionals are expected to master strategies, methodologies and tools that promote the real learning, interaction, progress and growth of their future clients and work teams.

As a teaching, research and extension institution, the Federal Institute has a priority interest in the development of formative contexts that foster deepening and learning of strategies and methodological positions that lead to real learning and personal and professional growth.

In this sense, we ask ourselves: 1) in what way is it possible to promote curricular integration? 2) Can cooperative learning methodology enable curricular integration and provide better training for students?

\subsection{The Project and Project Research}

The research is essential to the teaching practice, because when the teacher assumes the position of researcher, he is committed to the questioning, to the pedagogical doing, with the challenges inherent in the new practices, with the discovery. When the teacher uses the pedagogical space - that is, the classroom as a research laboratory, he can create the necessary conditions to question and evaluate the pedagogical doing, to reflect on his praxis and, from the diagnosis in his successes or eventual Failures, to experience a constant state of preparation and improvement of their pedagogical practice.

From the methodological point of view, this project had elements of participatory research, action research and data collection procedures involved the participant observation and a semistructured questionnaire that was applied with the students of the class, as described in item 3 of this article. During the course of the project, concerns about the effective interdisciplinary integration present in the curriculum employed did not overshadow the daily work of teachers and students.

The field research was developed in the academic year 2015 in a Federal Institute of Education, Science and Technology, in the third year of the Technical Course in Integrated Administration to High School (São Roque campus, São Paulo, Brazil).

\section{The Teaching Project: Integrated Curriculum and Cooperative Learning - AN EXPERIENCE WITH THE THIRD Year OF THE TECHNICAL COURSE IN ADMINISTRATION INTEGRATED TO HIGH SCHOOL}

With the Teaching Project entitled "Integrated Curriculum and Cooperative Learning - an experience with the Technical Course in Integrated Administration to High School" several objectives were established: Integration of the curriculum through the curricular components of Projects and Entrepreneurship, Integrator and Arts Project; - Use of the methodology of cooperative learning and the development of awareness and creativity through sound, corporal, dramatic and artistic languages of art; - To prepare students for the practical application of a variety of teaching models based on cooperability and sharing in line with the advancement of technology, knowledge and diversity; - To verify and analyze interactions and cognitive, artistic, affective, social and interpersonal development in the practical application of different teaching strategies.

\subsection{The Choice of the Methodological Proposal of Cooperative Learning}

Considering the researches and practical applications in the use of Cooperative Learning and its results, it is very important to highlight that these studies clearly show that when compared to 
traditional models of learning with an individualistic or competitive focus, the experiences of cooperative learning promote better academic performance, better interpersonal relationships and more positive attitudes towards colleagues, according to several authors [2] [3] [4] [5] [7] [8] [11] [12] [15] [16] 17] [19] [20] [21] [23]. According to Slavin [18], "there is a strong positive effect between groups on cooperative learning" (p.181). In addition, research, programs, activities, and projects focused on cooperative learning in the field of academic performance, skills development, skills and values have been extensively and carefully presented and reviewed and all perform better in comparison to other teaching models.

Since the 1970s, the numerous references in the specialized literature have shown a renewed interest in understanding how cooperation processes work in learning, to their advantage when compared to individualistic and competitive models, or in the promotion of skills, values and interpersonal relationship.

To advance in the understanding of this research, some basic concepts are necessary to understand the applied methodology in the project development, the strategies of the work and the methodological vocabulary used in this article.

Cooperative Learning (AC) is a methodological proposal to organize teaching and learning processes with students working and studying in small groups, where the teacher or students coordinate their action in such a way that the general and specific objectives are achieved curricular components and educational training [2]. It is a model that favors achievement and productivity for students of all levels, as well as promotes intrinsic motivation, attention and critical thinking [7].

As it is a structural model, it can be affirmed that the Cooperative Learning works as a background for the application of diverse strategies that involve social interaction, development of competences and abilities, group dynamics, positive interdependence, individual and group responsibility And egalitarian participation [3]. It is a methodology in which students work in heterogeneous groups to solve a problem, complete a project or some other pedagogical objective. In the development of these activities, students will experience basic elements of Cooperative Learning, mostly indirectly: social interaction; individual responsibility; promoter interaction; development of social skills; group processing and positive social interdependence [1].

The importance of the interaction between the participants is amplified when one speaks of the 'promoter interaction'. It is the ability of the members of a group to share their knowledge with each other and to invest in each other's success. This interaction is directly linked to positive interdependence, since students interact and work at the same time in two ways: in the pursuit of individual academic success and in the quest for success of the other components of their group. When talking about promoter interaction, reference is made to the positive interactions between students based on cooperation. The choice of expression and concept comes from the cooperative studies of Johnson and Johnson [8], but can be initially understood in the light of Vigotsky [24], which made it very clear that students in interaction with the co-operation of study partners can move forward knowledge that they would not be able to perform alone in the so-called zone of proximal development (ZPD):

It is the distance between the actual level of development that is usually determined through problem-solving, and the level of potential development determined through problem solving under the guidance of an adult or in collaboration with more able peers. (VIGOTSKY, 1984, p. 58) [24]

This study deepens knowledge about working in groups in educational settings. Although it is an important element of cooperative learning, positive interdependence does not alone generate the required interaction intensity in cooperative learning strategies and activities. For this reason, it is essential to use the concept of promoter interaction also worked by Trytten [22]:

In the promoter interaction, group members need to know and believe that team success depends on the contributions of each member. They then need to know that the interactions promoted in the study groups are necessary for success and for the pursuit of common targets, all of which occur in the preparation and progress of activities that occur in face-to-face interaction. (p. 3).

In the promoter interaction it is necessary to work with small groups and thus maintain them, since they can more easily encourage mutual efforts [9]. In promoting interaction, students directly in 
groups "should promote each other's success (helping, assisting, supporting, encouraging and encouraging each other's efforts to learn)" (p.6). For these authors,

Doing so implies using cognitive processes such as verbally explaining how to solve problems, teaching knowledge to colleagues, connecting learning from the past to the present. This also leads to working in an interpersonal way with processes that challenge each other in reasoning and conclusions, examples and ways to facilitate learning. This will facilitate learning efforts and students will give and receive verbal and non-verbal feedback. (JOHNSON, JOHNSON e SMITH, 1998, p. 6). [9]

In this sense, although the terms' cooperation 'and' interaction 'can be conceptualized subjectively or abstractly, they present themselves as postures and objective attitudes in students' behavior in groups and school teams that promote learning through cooperative postures. In this research we take as a basis Piaget's presentation and defense of cooperation and interaction, especially when valuing teamwork in the school environment [3] (p.34). In addition, he emphasizes that in dealing with others in interaction, our "reason needs cooperation, insofar as the rational being consists in" situating "itself to submit the individual to the universal" (p. And in showing how to help the young in their development, facing individualistic or egocentric attitudes and mentalities, Jean Piaget is emphatic: "Only cooperation corrects this attitude, thus attesting that it exercises, in the moral domain as in the things of intelligence, A role at once, liberating and constructive "(ibid., 299) [14].

Slavin [19] stated in the summary of his research on academic performance in cooperative learning that cooperative methods incorporating goals and targets into group work associated with individual responsibility greatly accelerate student learning. For him, current knowledge is more than sufficient to justify the use of cooperative learning as a central element of teaching and as a necessary routine in schools. In addition to promoting the learning of skills and values of interpersonal relationships and improving academic performance, researchers at the University of Minnesotta have concluded that cooperative learning promotes improvements and growth of self-esteem and positive attitudes towards the school and toward teachers [10]. In short, cooperative learning can be synonymous with various ways of promoting work in groups and teams in teaching and learning processes.

\section{The Organization of the Teaching Project: Experiences and ACtions}

The Teaching Project referred to in this article was developed in a class of 24 students from the 3rd year of the Technical Course in Integrated Administration to High School. Six teams of four students were organized to develop the proposed activities, using the cooperative learning methodology proposed by Carvalho [2] [3] [4].

The routine happened through the application of several dynamics elaborated from the demand of the contents in agenda and of the profile of the group, after which the works were developed obeying the proposals offered [3].

The stages of the work, as well as the partial results were recorded in films and photos for possible editing and development of an audiovisual material at the end of the school year.

The methodological process was based on the personal form of each group, but the steps planned include the following elements: Stimulus for inspiration; Resources for searching internal information; Space for some type of recording (sound, writing, expressed by drawing, etc.); Space for information exchange; Moment for creative organization (space in which the group or individual prints their own brand in the artistic product); Technical improvement; Finishing; Stage of exposure of the material; Dialogue and exchanges on what has been developed.

\subsection{Interdisciplinarity: Experiences, Actions and the Development of Activities}

All actions of this Teaching Project were carried out within the scope of the curricular components of Project Integrator and Projects and Entrepreneurship, in the 3rd year of the Technical Course in Integrated Administration to High School, under the guidance of Professors Anna Carolina S. Jardim and Maria Júlia Nogueira. The Prof. Frank V. Carvalho participated in the planning of actions and guidelines regarding the Cooperative Learning Methodology.

Throughout the first half of 2015 , several training meetings, orientation and guided studies on the methodology of cooperative learning and on professional and technological education were necessary to be able to elaborate the actions that would be applied in the classroom. 
Initially the project for the students was presented in an interactive dynamic in which they were stimulated to clarify doubts, give opinions and suggestions.

In order to find themes that sensitize the students, a work was done with paintings by renowned artists that dealt with the theme "Work". This is because the professional training is the basis of the curriculum of the technical courses offered by the Federal Institute. In this context, the students visualized the screens and the teachers explained about the daily work themes in different situations. It was important to bring the student world closer to the world of work so as to awaken in students an interest in social issues related to work. This awareness culminated in the production of drawings and paintings by the students where they demonstrated the themes that are important to them.

Throughout the second school month, actions were taken to stimulate creativity and cooperative behavior through the production of sounds and mimics using the body itself. Initially the students felt somewhat embarrassed, but gradually they were able to express themselves, as well as initiated a process of learning related to mutual respect both with respect to the individuality and the personal characteristics of each one, as well as in what refers difficulties in the content worked. As the work model progressed, whether conducted by the teacher in class or by the students when studying outside the classroom, they built teaching and learning relationships and shared knowledge with colleagues. Thus, the chances of academic development in the acquisition and construction of knowledge were increased, as well as opportunities for success in the joint search for solutions to the various proposed activities.

A presentation of the Universal Declaration of Human Rights, entitled "Dawning the 21st Century", was presented, interconnecting it to the multiple languages of art. The groups produced works related to the theme. Many social themes have appeared in the artistic productions of the students, among which stand out: pedophilia, sexual abuse, gender bias, violence in the family and society as a whole. The themes that they appreciate in the artistic productions of the students serve as a basis for the planning of the actions and themes that are included in the content to be developed during the school year, which allows to work ethical and social responsibility issues, clarifying the importance of these subjects for a good performance in the world of work. Songs were worked as repertoire so that the students knew several rhythms, tones, timbres, notes and other musical concepts. Simultaneously, the topics of 'Final Work of Course Conclusion' of each group, as well as the concepts of entrepreneurship were worked.

There was work on social entrepreneurship where students heard a radio interview with an entrepreneur and then took notes. With the musical repertoire of rhythms, sounds, timbres and melodies, the students chose a musical style typical of the northeastern region of Brazil, known as 'Repente', titled 'Tatá Engenho Novo' and from it, each group composed one or two Stanzas related to the concepts of social entrepreneurship and entrepreneurial profile. The groups performed in the auditorium and the teachers filmed the result, as well as discussed the concepts of entrepreneurship involved in the compositions.

Still trying to develop entrepreneurial behavior, stimulate creativity and contribute in an interdisciplinary way for the elaboration of the 'Final Work of Course Conclusion' were passed two videos to the students to improve the rhythm repertoire, the discussion of moral and ethical values, cultural differences and diversity: 1) video about dances and songs of the African people; And, 2) Video of the Stomp group, which uses everyday elements such as brooms, pans, tools, among others as instruments. It explored the rhythmic diversity of the videos and stimulated the production of works that stimulated the students' body expression.

The documentary video of Cássia Eller was seen as a way of introducing cinematographic genres and to resume discussions on the themes that appeared in the drawings and paintings realized in the first two months, such as diversity of gender, drugs, among others. In addition, the film should serve as a basis for the planning and elaboration of an artistic presentation involving the whole class about the book entitled "The secret of Luísa", where José Dornellas brings a plot to approach the contents related to the theme of entrepreneurship. By the end of the first two months the groups of students had already produced a text about the work.

The artistic presentation about the book was carried out by the whole class. The students were divided into two large groups on stage: those who sang and played musical instruments (bass and guitar); And those who dramatized and explained the concepts pertinent to entrepreneurship. There was also a video production by the students themselves. The musical presentation was based on the melody of 
the song "Eduardo e Mônica", by Brazilian band Legião Urbana, but the lyrics were composed by the students themselves based on the story of the book "The Secret of Luísa".

It is noteworthy that this artistic presentation brought great challenges for students. It was necessary to work with a short deadline, because although the presentation had been scheduled since the beginning of the year, they only got organized effectively for the work on the eve of the presentation date. This fact brought new elements of learning, as it generated conflicts, difficulties in giving up and giving up one's own ideas for the ideas of others, as well as in the division of one's work into the composition of the whole. The result was very positive and excited the teachers, because the participation of all together increased the learning processes significantly and created conditions for the active and frequent participation of students in the activities of the groups. In addition, it interfered positively in the teaching and learning processes, as the proposals of work and group activities made each student have a responsibility and a real commitment to the learning in the activities promoted in the group in the classroom or outside. The opportunities for participation were, in the proposed activities, real, frequent and inclusive.

\section{Evaluation and Analysis of Participation and Development of Students - QUANTITATIVE AND QUALITATIVE ANALYSIS}

The evaluation and analysis of participation in relation to the methodological strategies used show the commitment and student perspectives throughout the development of the project. In fact, there was qualitative growth as the answers clearly indicate. The technical features of the Project regarding participation and registration were followed (Free and Informed Consent Term, written records, Participation Analysis Questionnaire) and made possible a comprehensive analysis. The semistructured questionnaire was applied to 18 students, since 6 students missed classes on the day of application and 1 student preferred not to respond, claiming that they would not like to express themselves formally about the project. By participating, listening and being heard, learning and teaching, growing and interacting, sharing and receiving, accepting others and being accepted by the team - each student saw himself as a participant and active member of the group to which he belonged - as one who effectively acts in the Process of teaching and learning, corroborating with the researches and concepts developed by Carvalho [4]. In a qualitative approach, the questionnaire focused on individual perception regarding the didactic-methodological paths used and the growth in learning and interaction with peers. Among the 18 participants in the questionnaire, 55.5\% of the participants were female, and $44.5 \%$ were male. Regarding the answers, there was a balance in the distribution of responses, with no gender preponderance regarding participation, safety, responsibility and involvement.

The first question of this study was thus presented, having, after, the choice of one of the three alternatives, the possibility of justifying the answer:

"1. In the proposed activities, there is always a need to divide responsibilities. How do you assess "your commitment to take responsibility" in group tasks and activities?

( ) It has always been the same since the beginning of the Project.

( ) Has grown during the execution of the Project.

( ) Decreased since the beginning of the Project.

Justify your answer:..."

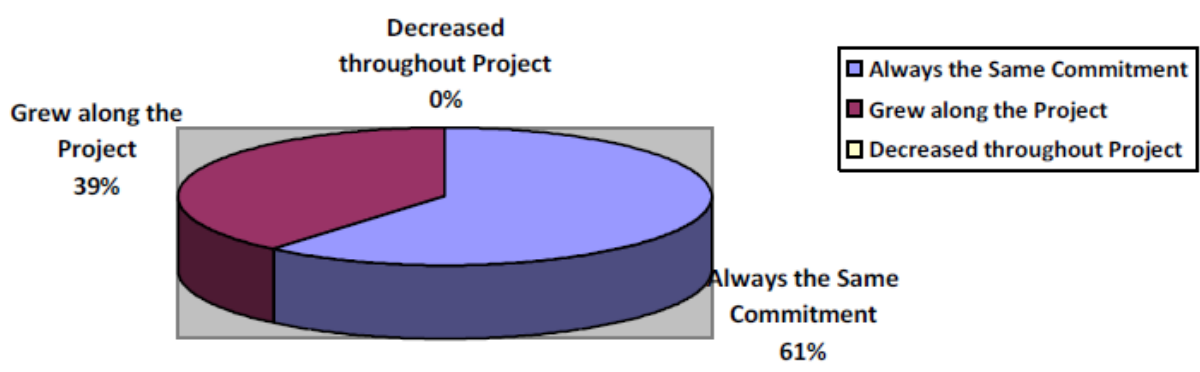

Graph1. Commitment to Assuming Responsibility for Proposed Activities

Source: Developed by the Authors

Among the participating students, none of them had diminished their interest in participating in the Project and engaging in group activities. Of the two possible positive responses, $61 \%$ affirm that they 
have entered and remained motivated and 39\% have increased their commitment and commitment throughout the development of the Project, a fact that corroborates the results found in previous researches [2] [7] [7] 8].

Regarding the qualitative aspect, the answers presented several justifications. Of those who responded that their commitment was the same from the beginning of the Project, several explanations stand out:

"From the beginning I tried to keep a rhythm, helping in the stages and completion of the work".

"I have not changed since the beginning of the group, I continue to collaborate with all the works."

"It was the same because it was kind of difficult to deal with the group."

"It was always the same way I always tried to help my group as I could giving ideas to do the task in a way that everyone in the group agreed."

"I've always been committed and responsible to myself and the group that I work with, I've never changed my attitudes and behaviors no matter who I was working with."

"It was always the same, because even though it seems that not, I always carry out the task in the best way possible, and I keep this attitude so I do not see something 'negative' (delay, incomplete, etc.)."

"I have always helped in the activities in both groups, helping the group make decisions."

"In all the activities of the project we tried to divide the tasks and everyone exercised the same responsibility over them, which would be to do everything possible to carry them out."

"Since from the beginning I have dedicated myself with the same intensity and strength of will as now."

"Each person in the group talked about what they could do and so we have been dividing the responsibilities since the beginning of the project."

It is observed among the respondents that "being committed" to the group and to the proposals of tasks is something that goes beyond the limits of the tasks and activities developed in this Project of Teaching, since these students are seen as committed to the school activities in general. It is also noted that the individual contribution in the decision-making processes, as well as the division of tasks are of great importance for the group researched.

Among those who answered that their degree of commitment increased during the Project, the following answers stand out:

"With time (days) getting smaller, the" twinge "of responsibility has more effect, thus bringing more commitment to reach the goal and the expected date for completion of projects.

"Throughout the year my commitment was good with several group decisions."

"It has grown, because with the intimacy of the pair growing and time decreasing, the responsibility increases."

"I have been collaborating more and more in the works so that it gets better and better."

"It depends on what the project was demanding."

"With the responsibilities of each job and presentation, my growth and the way I deal with problems and challenges have improved significantly."

"I realized that I developed a bit more about the project, talking to other people, losing some of the shame of presenting works and expressing myself through them."

Again, the decision-making process is of great importance to the research group and that the development of the Teaching Project has helped them to improve interpersonal relationships, as well 
as encouraged appropriate communication and conflict resolution, as observed by other cooperative learning researchers [1] [2] [3] [7] [10]. It was also useful for the development of communication and expression of students, especially the more timid.

The second question had to do with individual perception of group harmony, since this analysis, while having an internal bias in the response (someone outside the group could do a diametrically opposite value analysis), also allowed to see how individually the overcoming the difficulties of teamwork led its components to growth - this could be seen in the justifications of the answers. This question also allowed the choice of one of three alternatives, and in the end asked for a justification:

"About Interaction and Harmony with Your Group: When we work as a team, sometimes different opinions lead to disagreements and tensions. In order to preserve the good relationship of the group, these issues need to be discussed so that the problems are solved and the tasks performed. At this point, how do you rate your group:

( ) We had problems, but we always discussed in a pleasant way and we managed to solve them.

( ) At first we face difficulties, but over time we can improve our way of solving problems.

( ) We practically had no problems and we were harmonious from the beginning.

Justify your answer:..."

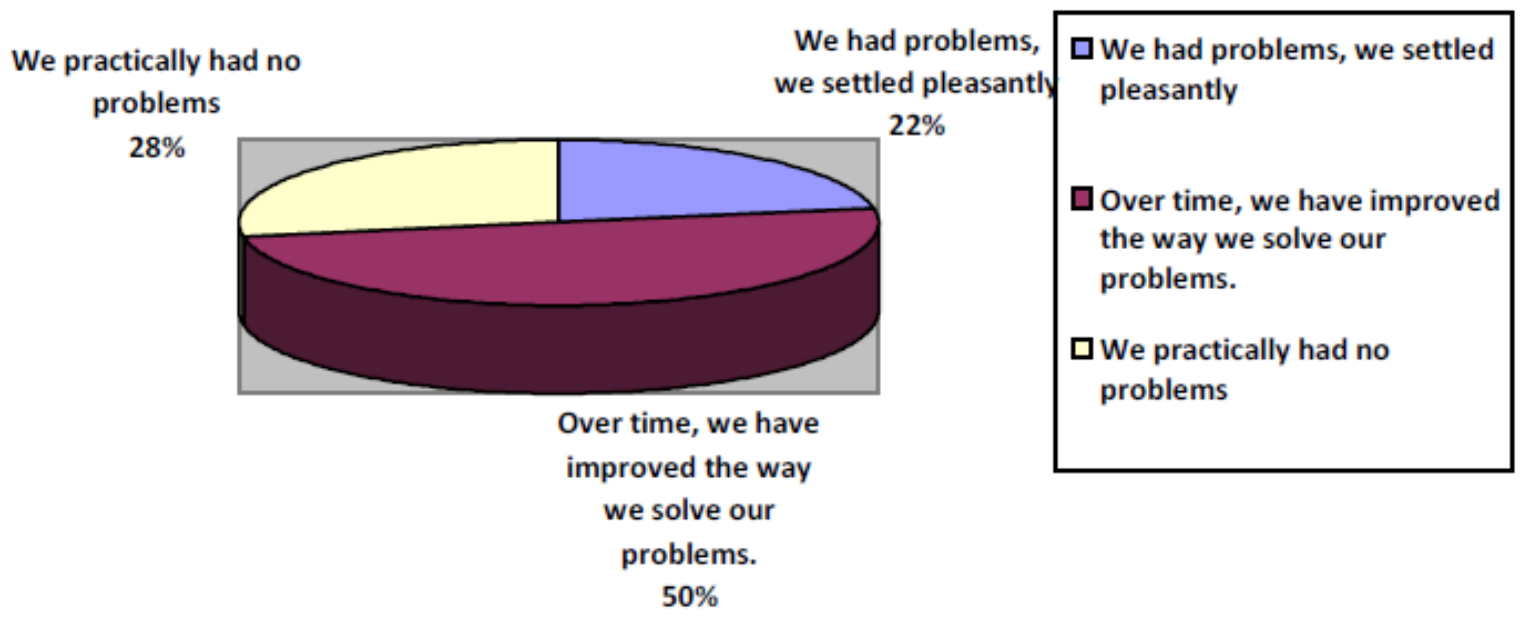

Graph2. Group Harmony

Source. Prepared by the authors

This is a more complex question and in a quantitative analysis, it is worth noting that $50 \%$ pointed out a natural logic in the methodological work of the teams in groups in the classroom: it is along the way, or in the course of teaching and learning activities that a group find the best way to solve problems. In fact, the maturation of relationships enables this growth of the group - this occurred with half of the groups or participants. To solve problems in an always pleasant way (22\%) is to admit the existence of problems, but the choice of a consensual way to solve them. And $28 \%$ said they had practically no problems.

In the qualitative answers we see that the groups have followed interesting paths in their interaction in the search for the solution of the problems. Among the justifications for those who have always solved the problems in a friendly way, the following stand out:

"Their point of view, although very similar, sometimes showed unseating, but was quickly resolved."

"All groups when assembled there are conflicts, however, how they resolve such conflicts that is the case. With ours it was not different, because we managed to deal with such quarrels in a good way (in my group). With the whole class there is always conflict, because a certain group of the room is never content with anything and complicates the relationship of the room in general. " 
"We had problems because the group is big and there are several opinions and some of them absurd that it did not deserve a yes as an answer."

"We both have a similar view of things so we solve problems very easily."

Those who, over time, learned and evolved in the way of solving problems, justified this:

"There were some differences between us, but as time went on we became accustomed to each other's personality and we went well."

"With many opinions on a particular topic, disagreement (since each opinion has its own), but with a good conversation we had a result."

"At first we had communication problems with some members of the team and more disagreements afterwards we talked and we were able to enter into an agreement."

"In my TCC work, I and my colleague have never had problems, we always attach importance to each other's opinions and we always enter into an agreement, without any conflict. But when the whole room had to do a job together we had a lot of discussion and disagreements thanks to our different thoughts and opinions, but in the end we came to an agreement and the work was very well presented and elaborated."

"There will always be one person who disagrees with the other, whether they are brigades or not liking each other. A lot of it was part of my group, but because it's work and work, do not kid yourself, my group was discussing in a positive way raising arguments that would be more positive for the group and we also know how to deal with criticism."

"At first we had some misunderstandings, but as time went by each one got the idea of the colleague, and so he accepted the idea of each one."

"At first some members of the group wanted to" cheer ", but soon they were creating responsibility".

"The differences caused within the group have always been controlled and respected to arrive in a sense. But when the task integrates the whole room there are bigger problems, like discussions. But despite the difficulty, the room was resolved (not pleasing at all) ".

"At the beginning of the CBT there were some disagreements, but after a while we were able to solve this problem."

The longer a group stays together, the greater the chances that its components will learn to solve issues and problems from teamwork and learning-driven interaction. It is observed that if these groups were 'broken' in only one class or activity, these students would not have the opportunity or possibility to 'learn' how to resolve conflicts and difficult issues of interpersonal relationships, even if they were focused on teaching and learning, Which confirms the importance that Carvalho [2] [3] and [4] gives to the maintenance of the same group of individuals over time.

The third question involved aspects related to promoter interaction - that is, the issue related to knowledge sharing - which, in the case of working in teams, means teaching and learning relationships. It certainly involves personal security, mastery of knowledge, promoter interaction and understanding of the processing of activities within the group. The answers show how much these students walked in this development of skills of teaching and learning in the collective work, as emphasized by Trytten [22]. This question presented four alternatives and in the end asked for a justification:

"Do you think any classmate has learned anything directly from you about the content studied?

( ) No, because I did not teach, for I did not know;

( ) I even knew it, but I did not teach it because I did not feel comfortable doing it;

( ) I think my colleagues learned from me; 
( ) I'm sure my classmates have learned from me.

Justify your answer:..."
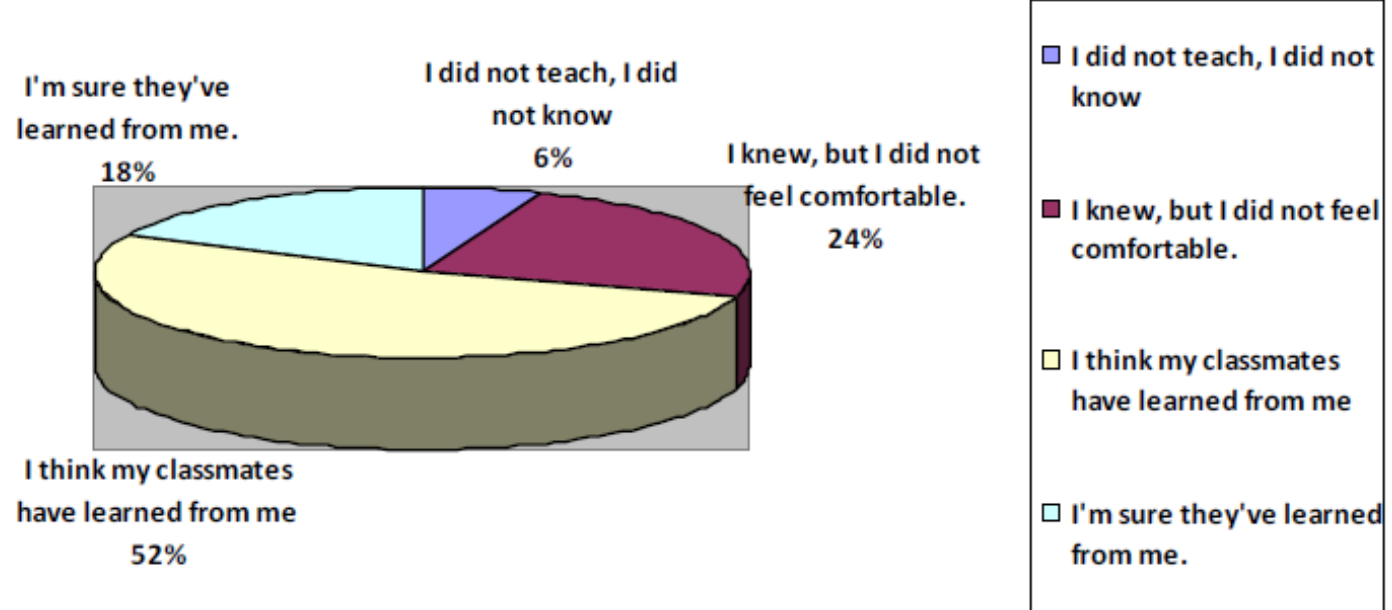

Graph3. Promoter interaction - Sharing knowledge

Source. Prepared by the authors

Here two large groups of answers present themselves to a question that seeks to examine how much the students can teach each other, as long as situations are created that promote activities of mutual teaching in the team work of the school perspective. The last two alternatives of the question are of a positive focus, since they only vary in the security and certainty of the respondent as to what he taught and how much he perceived the effectiveness of this action. The largest group, 52\%, "think" that colleagues learned from their participation, with their participation in the process of teaching in collective work. And 18\% still show greater certainty, as they chose "I'm sure ... they learned from me". This leads to $70 \%$ (or seven out of ten) of the participants who affirmed this highly positive aspect of the promoter interactions.

It is noteworthy that those who chose the second alternative could also promote the same action however, the answers show that something was still missing, perhaps greater security. The same can be achieved as more activities of this nature are promoted. Thus, 24 percent, or one in four students, say they "knew" but "did not feel comfortable" to teach their classmates. There is no doubt that the field of explanations for this 'limitation' is broad - the justifications will show this. And lastly, $6 \%$ did not teach because they did not know - which shows that teaching activities, whether individualized or group, need reinforcement and assistance to be successful. Let's see the justifications:

The following are the justifications for the four possible responses of the students. In the first, only one student was justified:

"No, because I did not teach, because I did not know. I learned from all the classmates in the room, with the teacher explaining what it is to do with that activity."

In the second alternative, the one that shows the issue of security or insecurity in sharing (or other motives and feelings):

"I did not feel well, because many closed and did not let other opinions be given to carry out the work."

"I could not explain it to them."

"I did not feel comfortable."

"In some activities I even knew and explained what I knew, but at no point did I want my understanding [sic] to be taught to them."

The students who pointed out the third alternative, were justified:

"I think some of my colleagues learned from me, yes, I'm very good at communicating."

"Yes, because I am a creative person and I hope they learned this from me." 
"I think something they have learned from me, I have always been severe [sic] in school work, and I take a lot in people's feet so in one way or another some knowledge they will get with me."

"Because I saw it was an obligation" [to teach within the group].

"I believe that artistically I had to teach, even against my will, my colleagues to perform some functions (such as painting.)".

"At issue with the workgroup of the classroom not so much, because I do not know much about art, I learned from them, already on the subject of CBT yes, because I have more knowledge about the subject studied."

"I think something they learned from me, because I explained things at work."

"Everyone over time learns from our peers, I think I may have taught some things."

And lastly, those who marked the fourth alternative, showing great security in affirming their participation in teaching their colleagues:

"Because it was a double, the exchange of information was inevitable."

"In the same way that I learn from my colleagues, they learn from me too, it may not be a lot of important information, but it's the ones that make the difference."

"With the interaction between the two of the pair is easy to learn from each other."

"I do not know if I was able to help them in the face of their difficulties, but I believe they do, just as they helped me."

\subsection{Difficulties and Challenges}

The first difficulties came with the design of the project and the first few weeks of implementation. It was necessary to know the expectations of each of the teachers, as well as their ways of working, of dealing with students, of sharing a classroom. An important aspect is that the teacher in the Administration area had already worked with the class, which assured her a positive insertion, since she had previously established an affective relationship with the class. The art teacher was gradually winning the respect and affection of the students. There were delicate situations in the interpersonal relationship, but as the work was being developed, the edges were trimmed and the development of affectivity was initiated in a reciprocal way.

From the point of view of the students it was notorious the difficulty in understanding the Teaching Project and the relation between the Art and the contents that should be developed in the curricular components of 'Projects' and 'Entrepreneurship' and 'Integrating Project'. At first the students complained a lot and asked about when they would have a traditional class. They had difficulties of concentration, especially, in the moments in which they were taken to the stage of the auditorium. However, all participated actively in the proposed activities throughout the year 2015.

Insofar as they were involved in the activities, the greater the exchanges and interactions within the groups and the reflection of this was translated in the accomplishment of the activities and in the understanding of the importance of the collective work to reach the established goals. The construction of a questionnaire that reflected the degree of commitment, engagement and development from the individual perspective was also one of the challenges of the teachers.

Regarding the orientation of the 'Final Work of Course' (in portuguese TCC) to be developed by the student groups, the challenges multiplied along the way, but the goodwill of all and the certainty of overcoming encouraged them. In this case, it is a requirement to obtain the diploma of the Technical Course in Integrated Administration to High School. It is observed that this work generated insecurity, stress and demotivation in the group, requiring great skill on the part of the teachers to stimulate the production of the works in the best possible way. One of the mechanisms that worked was a rigorous schedule in which the students built their work in stages. The incorporation of a social bias into the research themes was stimulated and, simultaneously, the groups should seek information from the entrepreneurs of the municipality and region. This action aimed at bringing together the theories 
developed throughout the course and the daily life of the work world, so each group was able to choose its theme of TCC, focusing on the different areas of the Administration.

\section{Final Considerations}

The retrospective look, both in the scientific research aspect and in the project realization aspect, left the organizing team very satisfied. Operating an integrated curriculum through faculty and student actions is a possible and highly rewarding challenge. The disciplines in fact dialogued with each other, as the narrative of the project and the activities in this article demonstrated. The use of the methodology was shown to be quite correct, since in addition to enabling the students' development, it led them to new experiences in sharing ideas and knowledge in a practical way. Working in teams also made it possible to achieve the goals in relation to the content proposal of the curricular components involved. The answers to the questionnaire, whether in the quantitative aspect, or in the qualitative analysis showed the development of the students. In the project's progress, there was no doubt about the development of awareness and creativity through artistic languages. The knowledge derived from this research and practice can be useful in establishing pedagogical practices that promote the understanding of the integrated curriculum, greater student learning and conscious pedagogical interventions. The proposed strategies stimulated and stimulated the learning and development of the multiple skills, competences and personal and professional values that the Federal Institute wishes to teach.

It was gratifying to note that the steps were successful in preparing students for cooperation and sharing in line with the advancement of technology, knowledge and diversity. It is hoped that the knowledge derived from this project can serve as a basis for new strategies of interdisciplinarity in the application of the integrated curriculum, where the disciplines dialogue with each other, in fact promoting student learning as well as the principles of cooperative learning can serve as a basis To a more just and humanized society.

\section{REFERENCES}

[1] ANDRADE, Manoel in VIEIRA, Hermany Rosa. Avaliação do processo de ensino e aprendizagem entre articuladores de células do programa de aprendizagem cooperativa em células estudantis da Universidade Federal do Ceará. Dissertação de Mestrado em Educação em 27 de março de 2015, Universidade Federal do Ceará, página 24. Disponível em: http:// www.repositorio.ufc.br/bitstream/riufc/12566/1/2015_dis_hrvieira.pdf (acesso em 16/02/ 2016)

[2] CARVALHO, Frank Viana. Pedagogia da Cooperação: trabalhando com os grupos através da Aprendizagem Cooperativa. Engenheiro Coelho-SP, Editora UNASPRESS, Edições de 2000 e 2002.

[3] CARVALHO, Frank Viana. Trabalho em Equipe, Aprendizagem Cooperativa e Pedagogia da Cooperação. São Paulo, Editora Scortecci, 2015.

[4] CARVALHO, Frank Viana. Cooperative Learning in Brazil. IASCE (International Association for the Study of Cooperation in Education) Newsletter Volume 35 Number 3, December 2016.

[5] GONÇALVES, Lúcia Maria Pereira. A aprendizagem cooperativa: contributo para a melhoria das competências cognitivas e sociais de alunos com e sem N. E. E.'. Dissertação de Mestrado, Universidade de Trás-os-Montes e Alto Douro, em Vila Real, Portugal, 2010.

[6] JOHNSON, Roger T., JOHNSON, David W. e SCOTT, Linda. "The Effects of Cooperative Teaching and Individualized Instruction on Students - Academic Attitudes and Achievements". Journal of Social Psychology 104:2 (abril de 1978), pp 207-216.

[7] JOHNSON, David W., et all., "Effects of cooperative, competitive, and individualistic goal structures on achievement: A meta-analysis", Psychological Bulletin 89:1 (janeiro 1981), pp. 47 62. Link: http://psycnet.apa.org/index.cfm?fa=buy.optionToBuy\&id=1981-05387-001

[8] JOHNSON, Roger T. e JOHNSON, David W. "The socialization and achievement crisis: are the Cooperative Learning Experiences the solution?", Applied Social Psychology Annual 4 (Beverly Hills, California, Sage Publications, 1983), pp. 119-159.

[9] JOHNSON, David W., JOHNSON, Roger T., SMITH, Karl. "Cooperative Learning Returns To College: What Evidence Is There That It Works?" USA, Universidade de Minnesotta. Review Change, 30(4), 26-36. 1998. Link: http://www.sjsu.edu/advising/docs/Cooperative Learning.pdf 
[10] JOHNSON, Roger T., JOHNSON, David W. "Cooperative Learning will never die". Lecture delivered at the World Congress of Cooperative Learning in Odense, Dinamarca. (01a03/10/ 2015). Anais do IASCE disponíveis em http://iasce2015.ucl.dk/home/programme/ conferenceoverview/Acesso em 01/11/2015.

[11] MOREIRA, Joana Isabel Dias. A aprendizagem cooperativa: Aplicação ao $8 .^{\circ}$ ano de escolaridade na disciplina de História. Relatórios finais do Mestrado em Ensino de História e Geografia, Universidade do Porto, Portugal, 2012.

[12] NEWMANN F. M. e THOMPSON, J. "Effects of Cooperative Learning on Academic Success in Secondary Schools: A Summary of Research". Madison, Wisconsin: University of Wisconsin, National Center on Effective Secondary Schools, (1987).

[13] PIAGET, Jean. A Educação da Liberdade. Conferência apresentada no $28^{\circ}$ Congresso Suíço dos Professores em Berna em 8 de julho de 1944. Disponível em http://frankvcarvalho.blogspot.Co m.br/ 2015/11/jean-piaget-educacao-da-liberdade.html. Consulta em 01/11/2015.

[14] PIAGET, Jean. O juízo moral na criança. São Paulo, Summus Editorial, 1994.

[15] RAMOS, Rita. A aprendizagem cooperativa no ensino-aprendizagem das Ciências Naturais - o método STAD'. Dissertação de Mestrado, Universidade de Trás-os-Montes e Alto Douro, em Vila Real, Portugal, 2008.

[16] RIBEIRO, Celeste Maria Cardoso. Aprendizagem cooperativa na sala de aula: uma estratégia para aquisição de algumas competências cognitivas e atitudinais definidas pelo ministério da educação - Um estudo com alunos do $9^{\circ}$ ano de escolaridade'. Dissertação de Mestrado, Universidade de Trás-os-Montes e Alto Douro, em Vila Real, Portugal, 2006.

[17] SHARAM, Yael Sharam e SHARAM, Shlomo. "Group Investigation Expands Cooperative Learning”. Educational Leadership Magazine. USA, Virginia, dezembro de 1989, janeiro de 1990. Link: http://www.ascd.org/publications/educational-leadership/dec89/vol47/num04/toc .aspx

[18] SLAVIN, R. E. "Individualized Assisted Teamwork: Combining Cooperative Learning and Individualized Instruction in Mathematics". In: SLAVIN, R. E.; SHARAM, S.; HERTZLAZAROWITZ, R.; WEBB, C.; SCHMUCK, R. (Org.) Learning to cooperate, Cooperate to learn. New York, Ed. Plenum, 1985.

[19] SLAVIN, Robert. "Cooperative learning and Student Achievement". Educational Leadership, october, p. 31-33, 1988. Link: https://pdfs.semanticscholar.org/6e3f/efa2d36c58cf5df0 b040fe3d 029cc77d1022.pdf

[20] SLAVIN, Robert. "Research on Cooperative Learning: Consensus and Controversy". Educational Leadership 47:4 (dez 1989/jan 1990), pp. 52-54. Link: http://www.ascd.org/publi cations/educational-leadership/dec89/vol47/num04/toc.aspx

[21] TJOSVOLD, Dean e JOHNSON, David W. "Controversy and Cognitive Perspective-Taking". Contemporary Educational Psichology 3 (1978), pp. 376-386. Link to full text: https://eric.ed .gov/?id=ED151777

[22] TRYTTEN, Deborah A. "Progressing from Small Group Work to Cooperative Learning: A Case Study from Computer Science". Proceedings of the 1999 Frontiers in Education Conference, San Juan, Puerto Rico, 10-14 November 1999, IEEE Catalog No. 99CH37011, pp. 13a4-22 through 13a4-27, () 1999 IEEE. Link: http://onlinelibrary.wiley.com/doi/10.1002/j.2168-9830.2001.tb 00572.x/ full And Positive Interdependence, Individual Accountability, Promotive Interaction: Three Pillars of Cooperative Learning, link: https://www.uwstout.edu/ soe/profdev/ resources/ upload/acl_piiapi.pdf

[23] VIEIRA, Pedro Nuno Bessa Vieira. Estratégias alternativas de ensino-aprendizagem na matemática: estudo empírico de uma intervenção com recurso à aprendizagem cooperativa, no contexto do Ensino Profissional. Dissertação de Mestrado, Universidade do Porto, Portugal, 2000.

[24] VIGOTSKY, Lev Semenovich. A formação social da mente. São Paulo, Editora Martins Fontes, 1998, $191 \mathrm{p}$. 


\section{AUTHORS' BIOGRAPHY}

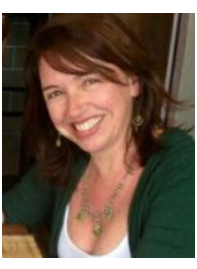

Anna Carolina Salgado Jardim, Concluding the Doctorate Degree in Education Psychology of Education: Pontifical Catholic University of São Paulo (PUC-SP), Brazil. Professor of Basic, Technical and Technological Education of the Federal Institute of Education, Science and Technology of São Paulo - Campus São Roque (IFSP-SRQ). NEARS Associate Researcher - Center for International Studies in Social Representations - PUC / SP. Email: annajardim9@gmail.com

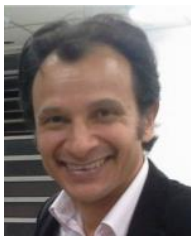

Frank Viana Carvalho, PhD in Philosophy University of São Paulo, Brazil. Professor of Basic, Technical and Technological Education of the Federal Institute of Education, Science and Technology of São Paulo - Campus São Roque (IFSP-SRQ). Researcher member of the IASCE - International Association for the Study of Cooperation in Education and Coordinator of the Project 'Pedagogy of Cooperation'.Email: fvc.frank@gmail.com 